\title{
Industrial Source Contributions and Health Risk Assessment of Fine Particle-Bound Polycyclic Aromatic Hydrocarbons (PAHs) during Spring and Late Summer in the Baoshan Area, Shanghai
}

\author{
Weiqian Wang ${ }^{1}{ }^{(}$, Qingyue Wang $\left.{ }^{1, *} \mathbb{(}\right)$, Daisuke Nakajima ${ }^{2}$, Senlin Lu $^{3, *} \mathbb{C}$, Kai Xiao ${ }^{1} \mathbb{D}$, Tanzin Chowdhury ${ }^{1}$, \\ Miho Suzuki ${ }^{1}$ and Fenwu Liu ${ }^{4}$ \\ 1 Graduate School of Science and Engineering, Saitama University, Saitama 338-8570, Japan; \\ weiqian@mail.saitama-u.ac.jp (W.W.); xiao.k.662@ms.saitama-u.ac.jp (K.X.); \\ chowdhury.t.078@ms.saitama-u.ac.jp (T.C.); miho@fms.saitama-u.ac.jp (M.S.) \\ 2 Health Risk Center, National Institute for Environmental Studies, Ibaraki 305-8506, Japan; dnakaji@nies.go.jp \\ 3 School of Environmental and Chemical Engineering, Shanghai University, Shanghai 200444, China \\ 4 College of Resource and Environment, Shanxi Agricultural University, Taiyuan 030801, China; \\ lfwlfw2008@163.com \\ * Correspondence: seiyo@mail.saitama-u.ac.jp (Q.W.); senlinlv@staff.shu.edu.cn (S.L.)
}

check for updates

Citation: Wang, W.; Wang, Q.;

Nakajima, D.; Lu, S.; Xiao, K.; Chowdhury, T.; Suzuki, M.; Liu, F. Industrial Source Contributions and Health Risk Assessment of Fine Particle-Bound Polycyclic Aromatic Hydrocarbons (PAHs) during Spring and Late Summer in the Baoshan Area, Shanghai. Processes 2021, 9 , 2016. https://doi.org/10.3390/ pr9112016

Academic Editors: Andrea Petrella and Monika Wawrzkiewicz

Received: 29 August 2021

Accepted: 8 November 2021

Published: 11 November 2021

Publisher's Note: MDPI stays neutral with regard to jurisdictional claims in published maps and institutional affiliations.

Copyright: () 2021 by the authors. Licensee MDPI, Basel, Switzerland. This article is an open access article distributed under the terms and conditions of the Creative Commons Attribution (CC BY) license (https:// creativecommons.org/licenses/by/ $4.0 /)$.

\begin{abstract}
The main objective of this study was to examine the chemical characteristics, possible sources, and health risks of fine particle-bound Polycyclic Aromatic Hydrocarbons (PAHs) in the Baoshan area of Shanghai. Here, ambient particles with five-size ranges were collected during the spring and late summer of 2017. The PAHs were determined by the Gas Chromatography-Mass Spectrometry (GC-MS). Our results showed that the average mass concentration of 13 species of PAHs in spring and in late summer was $4.83(1.88 \sim 12.1) \mathrm{ng} / \mathrm{m}^{3}$ and $4.27(2.09 \sim 5.75) \mathrm{ng} / \mathrm{m}^{3}$ in Total Suspended Particles (TSPs), respectively. The higher PAH ratios ( $\mathrm{PM}_{1.1} / \mathrm{TSP}$ ) indicated that PAHs are mainly concentrated in $\mathrm{PM}_{1.1}$, especially in late summer. The values of $\mathrm{BaA} /(\mathrm{BaA}+\mathrm{CHR})$ were under 0.50 and IcdP/(IcdP+BghiP) were in range from 0.20 to 0.50 for TSP and $\mathrm{PM}_{1.1}$, suggesting that petroleum combustion and diesel emissions could be considered as key sources of PAHs, which tend to be associated with $\mathrm{PM}_{1.1}$. Moreover, the Principal Component Analysis (PCA) in $\mathrm{PM}_{1.1}$ identified the main $\mathrm{PH}$ sources, which include stationary and diesel emissions. The air mass backward trajectories and wind direction analysis showed that air masses were mainly derived from marine sources across the local industry area in late summer. Individual Carcinogenic Risk Inhalation (ILCR) was over $10^{-6}$ among the total six age groups in both of the sampling periods in TSPs, indicating the possible carcinogenic risk, especially for children and the young age group. Toxic PAHs belong to Heavy Molecular Weight (HMW) PAHs, especially Benzo[a]pyrene (BaP). Compared with $\mathrm{PM}_{1.1-2.0}$, the Combustion-Derived PAHs group (COMPAHs) and Carcinogenic PAHs (CANPAHs) were highly concentrated in $\mathrm{PM}_{1.1}$. Stationary sources, such as the developed steel industry, made a great contribution to the level of PAHs, especially in late summer.
\end{abstract}

Keywords: particle-bound PAHs; $\mathrm{PM}_{1.1}$; health risk; possible sources; steel industry; Shanghai

\section{Introduction}

Polycyclic Aromatic Hydrocarbons (PAHs) are extensive organic contaminants comprising two or more benzene rings. They are widespread environmental contaminants generated as a result of the incomplete combustion of organic materials, such as fossil fuels [1-3]. Based on an ambient temperature, the nature of aerosol, and species of PAH, the PAHs in the atmosphere exist in the vapor phase or absorbed into ambient particles. It has already been reported that the species of water-soluble inorganic ions in ambient particles could increase the solubility of toxic organic compounds, such as PAHs, by acting as surface-active agents [4-7]. With their low vapor pressure, PAHs with heavier molecular 
weights could be absorbed by the fine inhalable particles in the atmosphere. In addition, this has indicated that PAH compounds with $5-6$ benzene rings are usually associated with $\mathrm{PM}_{2.0}[6,8]$. PAHs are one of the first atmospheric pollutants to be designated as suspected carcinogens. Moreover, PAHs are highly lipid-soluble and rapidly distributed in a wide variety of tissues, with a marked tendency for localization in body fat. As a result, the United States Environmental Protection Agency (USEPA) has listed 16 species of PAHs as priority pollutants, and the World Health Organization (WHO) has established that the $\mathrm{BaP}$ quality standard is $1 \mathrm{ng} / \mathrm{m}^{3}[9,10]$. The most significant health impact of inhaled exposure to PAHs is the lung cancer risk in all of the living organisms. It has been reported that about $1.6 \%$ of lung cancer morbidity might be due to inhalation exposure from atmospheric PAHs in the urban areas of China $[3,4,11]$. Although atmospheric PAHs exist at very low concentrations, epidemiologic studies have linked long-term, low-level PAH exposure with various health outcomes, especially cancer patients among adults. PAHs are more notably carcinogenic to humans than individual hydrocarbons [12-14].

Shanghai is a global commercial and financial center with a population of over 24 million in 2014 [15,16]. As one of the largest industrial and commercial cities in China, the Shanghai area suffers from heavy human-induced impacts and rapid urbanization. The Baoshan area located in the northeastern part of Shanghai is the main industrial district, with developed steel industries and several international ports [17-19]. Shanghai, located on the eastern coast of China, experiences four distinct seasons (spring, summer, autumn, and winter). The Shanghai Environmental Bulletin (2017), issued by the Shanghai Environmental Protection Bureau (SEPB), reported that atmospheric $\mathrm{PM}_{2.5}$ values in the spring were normally heavier than in summer and early autumn [20]. Atmospheric PAHs from various sources are expected to continue to be displayed by spatiotemporal differences to raise the potential impacts on the environment and human health $[6,17,21]$. In this article, the main objective was to examine the chemical characteristics, possible sources, and health risks of fine particle-bound PAHs in two representative seasons, spring and late summer. The details of the study are as follows: First, we collected ambient particles with five-size ranges using a high flow rate sampler in the Baoshan area during the spring and late summer of 2017. Then, we measured the ambient PAHs composition by gas chromatography-mass spectrometry (GC-MS) and analyzed the PAH size distribution and chemical characteristics. Next, we evaluated the possible anthropogenic source by diagnostic ratios, PCA analysis, and air mass backward trajectories methods. Finally, we assessed the potential health effects using the inhalation exposure risk model, etc.

\section{Materials and Methods}

\subsection{Ambient Particulate Collection in the Shanghai Suburban Sampling Site}

Monthly $\mathrm{PM}_{2.5}$ from 2014 to 2016, shown in Figure 1a, indicated that $\mathrm{PM}_{2.5}$ in March and April was usually higher in September and October. The sampling campaign from 21 March to 7 April was called the spring sampling campaign (spring), and the so-called late summer sampling campaign (late summer) was conducted from 14 September to 4 October in 2017. Both the spring and late summer sampling sites were several hundred meters apart on the Baoshan campus of Shanghai University in Shanghai, as shown in Figure $1 \mathrm{~b}$. The sites were located on the ground, about $4 \mathrm{~m}$ in height above sea level, and we chose to ignore the impact of sampling location. There were several main traffic roads near these two sampling sites, and the steel group was located about $10 \mathrm{~km}$ northeast of the sampling sites [6]. An Andersen high-volume air sampler (AHV-600F, Shibata Co., Tokyo, Japan) was placed on the ground to collect the ambient particle samples with five-size segregations, such as particles with a diameter of $1.1 \mu \mathrm{m}$ or less $\left(\mathrm{PM}_{1.1}\right)$, particles with a diameter between 1.1 and $2.0 \mu \mathrm{m}\left(\mathrm{PM}_{1.1-2.0}\right)$, particles with a diameter between 2.0 and $3.3 \mu \mathrm{m}\left(\mathrm{PM}_{2.0-3.3}\right)$, particles with a diameter between 3.3 and $7.0 \mu \mathrm{m}\left(\mathrm{PM}_{3.3-7.0}\right)$, and coarse particles $(>7.0 \mu \mathrm{m})$ in an aerodynamic diameter. The air sampler flow rate was $0.566 \mathrm{~m}^{3} / \mathrm{min}$, and each sampling event lasted up to $48 \mathrm{~h}$. Ambient particles were collected on quartz fiber filters (Pallflex-2500QATUP, Tokyo Dylec Corp, Tokyo, Japan), with $6 \mathrm{~h}$ 
of heat treatment to remove any possible organic compounds. The filtered samples after collection were wrapped in an aluminum foil sealed bag and remained at $-30{ }^{\circ} \mathrm{C}$ until the compounds were analyzed. Simultaneously, the meteorological factors (Supplementary Table S1) were referred from Tianqihoubao website (http:/ /www.tianqihoubao.com/, accessed on 20 May 2021), and the air quality factors (Supplementary Figure S1) were referred from the aqistudy website (https:/ / www.aqistudy.cn/historydata/, accessed on 20 May 2021) during both sampling periods.

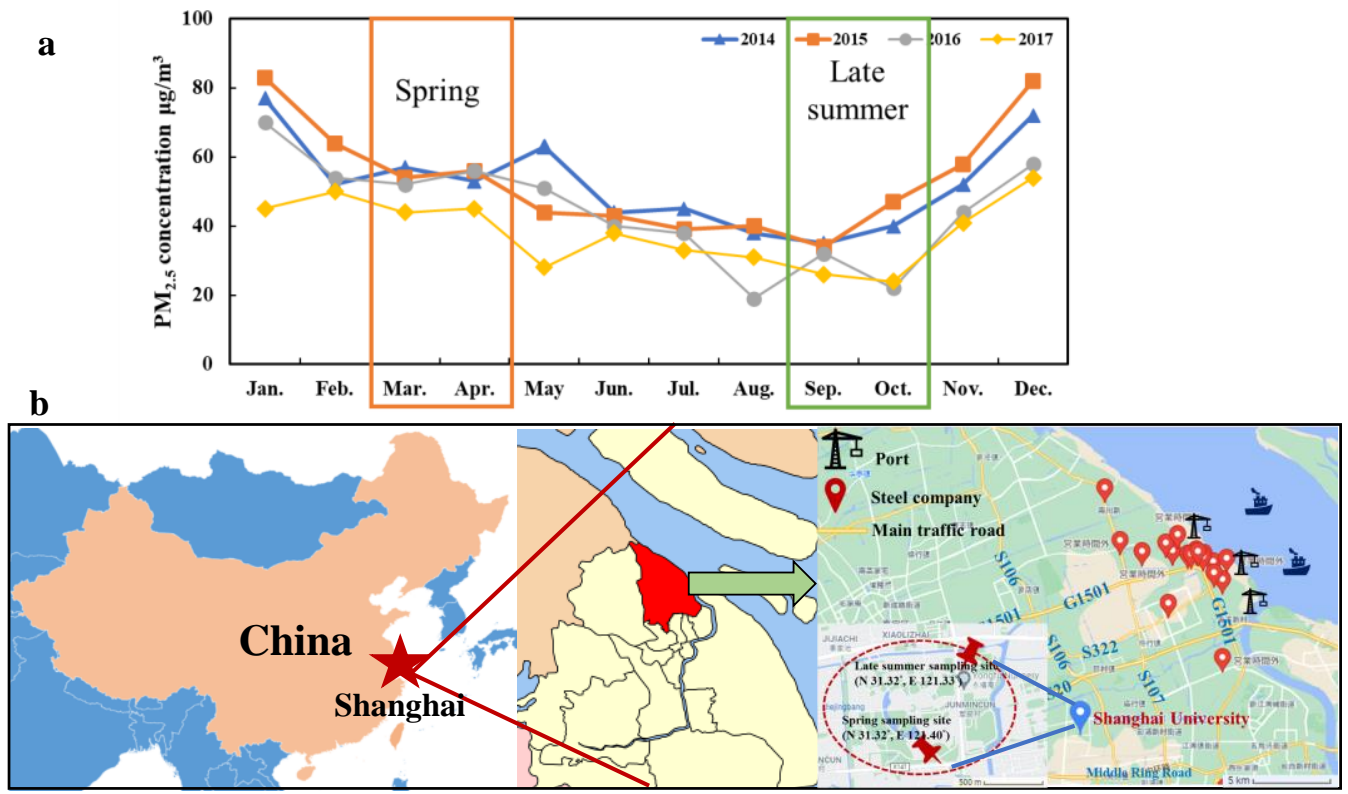

Figure 1. (a) Monthly $\mathrm{PM}_{2.5}$ values collected from SEPB from 2014 to 2017; (b) location of the spring and late summer sampling sites in Shanghai (the red mark of the steel company appeared on Google maps using the 'Baosteel' keyword in Chinese).

\subsection{PAH Analysis by Gas Chromatography-Mass Spectrometry (GC-MS)}

The PAH organic extraction method and GC-MS analysis system factor were mainly used from the (component analysis of fine particulate matter-manual for component measurement of fine particulate matter $\left(\mathrm{PM}_{2.5}\right)$ in the atmosphere), which was published by the Ministry of the Environment, Japan (https://www.env.go.jp/air/osen/pm/ca/ manual.html accessed on 21 May 2021). The detailed protocol was mainly followed from laboratory-published research [6]. The Sigma-Aldrich EPA 16 PAHs mixture was used as the standard chemical (Sigma-Aldrich, 4S8743, St. Louis, Missouri, USA). The extract solution with an internal standard was used in a volume of up to $0.1 \mathrm{~mL}$ and measured by GC-MS (GC-MS, Model Agilent 5973N, Agilent Technologies. Inc., Santa Clara, CA, USA). The GC-MS analyses were performed on an InertCap 17 column $(0.25 \mathrm{~mm} \times 30 \mathrm{~m}$ and $0.25 \mu \mathrm{m}$ film thickness) using an HP6890 GC interfaced into an HP5973 MS detector. The initial column temperature was $50^{\circ} \mathrm{C}$, and this temperature was held constant for $2 \mathrm{~min}$. Thereafter, the temperature increased from $15{ }^{\circ} \mathrm{C} / \mathrm{min}$ to $185^{\circ} \mathrm{C}$ and then from $8{ }^{\circ} \mathrm{C} / \mathrm{min}$ to $320^{\circ} \mathrm{C}$. This temperature was held constant for $22 \mathrm{~min}$. MS detection was run in the selected ion monitoring mode (SIM). The sample volume injection was $1 \mu \mathrm{L}$. High-purity helium was used as the carrier gas at a constant flow rate of $1.3 \mathrm{~mL} \mathrm{~min}{ }^{-1}$. The identification of the individual PAH was based on the retention time of the target ion peak (within $\pm 0.05 \mathrm{~min}$ of the retention of the calibration standard). Each sample was determined 3 times and the statistical analysis was processed by Microsoft Excel 2016. The analyzed PAHs were Acenaphthene (ACY), Anthracene (ACE), Benz[a]anthracene (BaA), Benzo[a]pyrene (BaP), Benzo[b]fluorathene $(\mathrm{BbF})$, Benzo[ghi]perylene (BghiP), Benzo[k]fluoranthene (BkF), Chrysene (CHR), Diben-z[a,h]anthracene (DahA), Fluoranthene (FLA), 
Fluorene (FL), Indeno[1,2,3-cd]pyrene (IcdP), Naphthalene (NP), Phenanthrene (PHE), and Pyrene (PYR).

\subsection{Source Apportionment Techniques of PAHs}

Recently, the PAH diagnostic ratios have been commonly used as a method for identifying and assessing pollution emission sources. Typical diagnostic ratios and their typical values are listed in Table 1 [6,17,22-24]. Furthermore, the Principal Component Analysis (PCA) was selected for use in identifying the PAH sources in $\mathrm{PM}_{1.1}$, which was performed using the SPSS statistical software package (SPSS 26, IBM, Endicott, NY, USA). The selected principal components have cumulative variances that exceed $85 \%$ of the total variance after the application of the varimax rotation. These factors could be considered in order to reflect the specific chemical sources of target pollutants $[25,26]$.

Table 1. Diagnostic ratios used with their typically reported values for particle processes.

\begin{tabular}{|c|c|c|c|}
\hline PAH Ratio & Value Range & Source & Reference \\
\hline LMW /HMW & $\begin{array}{l}<1 \\
>1\end{array}$ & $\begin{array}{l}\text { Pyrogenic } \\
\text { Petrogenic }\end{array}$ & Zhang, Wei et al., 2008 \\
\hline COMB/PAHs & $\sim 1$ & Combustion & Ravindra, Khaiwal 2008 \\
\hline $\mathrm{Fl} /(\mathrm{Fl}+\mathrm{Pyr})$ & $\begin{array}{l}<0.5 \\
>0.5\end{array}$ & $\begin{array}{l}\text { Petrol emissions } \\
\text { Diesel emissions }\end{array}$ & Ravindra, Khaiwal 2008 \\
\hline ANT/(ANT+PHE) & $\begin{array}{l}<0.1 \\
>0.1 \\
<0.4\end{array}$ & $\begin{array}{l}\text { Petrogenic } \\
\text { Pyrogenic } \\
\text { Petrogenic }\end{array}$ & $\begin{array}{l}\text { Pies, Carmen et al., } \\
2008\end{array}$ \\
\hline FLA/(FLA+PYR) & $\begin{array}{c}0.4-0.5 \\
>0.5\end{array}$ & $\begin{array}{l}\text { Fossil fuel combustion } \\
\text { Grass, wood, coal } \\
\text { combustion }\end{array}$ & Roberto, J. 2009 \\
\hline $\mathrm{BaA} /(\mathrm{BaA}+\mathrm{CHR})$ & $\begin{array}{c}<0.2 \\
0.2-0.35 \\
>0.35\end{array}$ & $\begin{array}{c}\text { Petrogenic } \\
\text { Coal combustion } \\
\text { Vehicular emissions, } \\
\text { combustion }\end{array}$ & $\begin{array}{l}\text { Akyüz et al., 2010, } \\
\text { Yunker et al., } 2002\end{array}$ \\
\hline IcdP/(IcdP+BghiP) & $\begin{array}{c}<0.2 \\
0.2-0.5 \\
>0.5\end{array}$ & $\begin{array}{c}\text { Petrogenic } \\
\text { Petroleum combustion } \\
\text { Grass, wood, coal } \\
\text { combustion }\end{array}$ & $\begin{array}{c}\text { Yunker, Mark B. et al., } \\
2002\end{array}$ \\
\hline Bap/BghiP & $\begin{array}{l}<0.6 \\
>0.6\end{array}$ & $\begin{array}{l}\text { Non-traffic emissions } \\
\text { Traffic emissions }\end{array}$ & Katsoyiannis 2007 \\
\hline
\end{tabular}

The Hybrid Single-Particle Lagrangian Integrated Trajectory (HYSPLIT) model is one of the most extensively used atmospheric transport and dispersion models in the atmospheric sciences community $[6,27,28]$. Air mass backward trajectories are calculated by the HYSPLIT model with the Global Data Assimilation System (GDAS) from the National Oceanic and Atmospheric Administration (NOAA) Air Resource to assess the air mass transport effort [26].

\subsection{Health Risk Assessment of PAHs}

\subsubsection{Average Dose Estimation}

An estimation of the absorbed dose could be considered as the result of the procedure for the determination of the exposure at risk assessment. The Lifetime Average Daily Intake (LADD) of the pollutant (e.g., PAHs) by inhalation could be calculated by the following equation [26]:

$$
\text { LADDi }=\frac{\mathrm{CA} \times \mathrm{IR} \times \mathrm{ET} \times \mathrm{EF} \times \mathrm{ED}}{\mathrm{BW} \times \mathrm{AT}}
$$

Here, the unit of LADDi (PAH) is $\mathrm{mg} /(\mathrm{kg}$. day), CA is the PAH (BaP) concentration $\left(\mathrm{mg} / \mathrm{m}^{3}\right)$ in the air, and CA (PAHs) is the converted BaP toxic equivalent (TEQ $\left.\mathrm{BaP}\right)$ by the 
Toxic Equivalency Factors (TEF) [29]. The TEF values for individual PAHs are as follows: BaP, 1; BaA, 0.1; BbF, 0.1; BghiP, 0.01; BkF, 0.1; CHR, 0.01; DahA, 1; FLA, 0.001; FL, 0.001; IcdP, 0.1; PHE, 0.001; PYR, 0.001.

IR is the volume of air inhaled per day $\left(\mathrm{m}^{3} \cdot \mathrm{h}^{-1}\right)$, ET is the exposure time $\left(\mathrm{h} \cdot \mathrm{day}^{-1}\right)$, $\mathrm{EF}$ is the exposure frequency (350, days.year ${ }^{-1}$ ), ED is the duration of exposure (year), BW is the individual body weight $(\mathrm{kg})$, and AT is the average exposure time (days). The average exposure time is calculated as $\mathrm{AT}=\mathrm{ED}^{*} 365$ to account for the lifelong nonthreshold carcinogenic effects of pollution. The LADD value, which is important for the determination of the exposure to carcinogenic contaminants, should be calculated. The calculated LADD value expresses the level of average lifetime exposure to estimate the probability of malignancy caused by the Individual Lifetime Cancer Risk (ILCR).

\subsubsection{Carcinogenic Risk Assessment}

A lifetime exposure scenario with different 6 age groups is as following, Group (Birth to 1), BW, $8.8 \mathrm{~kg}$, ED, 0.5 year, EF, 350, days $\cdot \mathrm{year}^{-1}$, ET, $1.5 \mathrm{~h} \cdot$ day $^{-1}$, IR, $5.4 \mathrm{~m}^{3} /$ Day; Group(1 to 6), BW, $14.5 \mathrm{~kg}$, ED, 3.5 years, EF, 350 days.year ${ }^{-1}$, ET, $1.5 \mathrm{~h} \cdot \mathrm{day}^{-1}$, IR, $9 \mathrm{~m}^{3}$ /Day; Group(6 to 16), BW, $43 \mathrm{~kg}$, ED, 11 years, EF, 350 days $\cdot$ year $^{-1}, \mathrm{ET}, 3 \mathrm{~h} \cdot \mathrm{day}^{-1}$,

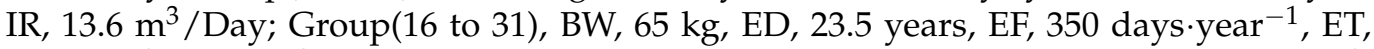
$3 \mathrm{~h} \cdot$ day $^{-1}$, IR, $16 \mathrm{~m}^{3}$ /Day; Group(31 to 51), BW, $71.2 \mathrm{~kg}$, ED, 41 years, EF, 350 days.year ${ }^{-1}$, ET, $3 \mathrm{~h} \cdot$ day $^{-1}$, IR, $16 \mathrm{~m}^{3}$ / Day; Group(51 to 81), BW, $70 \mathrm{~kg}$, ED, 66 years, EF, 350 days $\cdot \mathrm{year}^{-1}$, $\mathrm{ET}, 3 \mathrm{~h} \cdot$ day $^{-1}$, IR, $15 \mathrm{~m}^{3} /$ Day, separately. These exposure factors from the USEPA were used to assess the different age groups [26,30]. Additionally, the LADD is calculated for outdoor activities only. An estimate of the lifelong effects of a pollutant is used for health risk assessments of exposure to carcinogenic substances. The ILCR value could be calculated by the following equation:

$$
\text { ILCR }=1-\mathbf{e}^{(-\mathbf{I C P F} * \text { LADD })}
$$

Here, the ICPF refers to the inhalation cancer potency factor, which is equal to $3.9 \mathrm{mg} / \mathrm{kg}$. day for BaP [31]. The ILCR calculated by this formula is considered to be the theoretical increase in the probability of cancer occurrence above the general population average. When the ILCR value is lower than $1 \times 10^{-6}$, it could be considered an acceptable level of carcinogenic risk. This value can be interpreted as the probability of malignancy due to the harmful effects of a substance, which is higher than the normal occurrence in the case of one person in one million in an area with more than 100 exposed people.

\section{Results and Discussion}

\subsection{Size Distribution and Characteristics of Representative PAH Patterns}

Usually, Nap, Ace, and Ant are considered the main volatile PAHs reported, of which the total percentage found in the particulate phase is below 5\% [32-35], while the other 13 species of PAH classified as priority contaminants by USEPA were defined as mainly particle-bound PAH species (see Figure 2 and Supplementary Table S2). The average PAH values in the TSP were $4826.3 \mathrm{pg} / \mathrm{m}^{3}$ in spring and $4279.3 \mathrm{pg} / \mathrm{m}^{3}$ in late summer. In spring, the PAHs in TSP were high, reaching $12,060.45 \mathrm{pg} / \mathrm{m}^{3}$, in the March $25-26$ event and low, reaching $1884.53 \mathrm{pg} / \mathrm{m}^{3}$, in 29-30 March. Moreover, the higher $\mathrm{PM}_{2.5}, \mathrm{SO}_{2}$, and $\mathrm{NO}_{2}$ occurred during the 25-26 March event and it rained during 29-30 March, which could clean the air conditions (see Supplementary Figure S1). The Pearson Product-Moment Correlation Coefficient (PCC) analysis, given in Supplementary Table S3, indicated that the PAHs in TSP have a positive strong correlation coefficient with $\mathrm{SO}_{2}(\mathrm{r}=0.61)$ and $\mathrm{NO}_{2}$ $(\mathrm{r}=0.52)$ in spring. During the late summer, the PAH levels saw a high of $5747.12 \mathrm{pg} / \mathrm{m}^{3}$ on 14-16 September and low of $2070.95 \mathrm{pg} / \mathrm{m}^{3}$ on 29-30 September (a rainy event). In addition, the PAH levels showed a strong correlation with the daily average temperature $(\mathrm{r}=0.60)$ and a middle correlation with $\mathrm{O}_{3}(\mathrm{r}=0.49)$. Furthermore, the PAHs in TSP showed a strong correlation with the particle size. In particular, over 51.6\% (51.6 77.2\%) of PAHs in spring were associated with $\mathrm{PM}_{2.0}\left(\mathrm{PM}_{2.0}=\mathrm{PM}_{1.1}+\mathrm{PM}_{1.1-2.0}\right)$ and over 57.0\% (57.0 79.0\%) 
of PAHs in late summer were associated with $\mathrm{PM}_{1.1}$, which showed that the PAHs mainly associate with fine particles and were highly concentrated in the fine particles of $\mathrm{PM}_{1.1}$ in late summer.

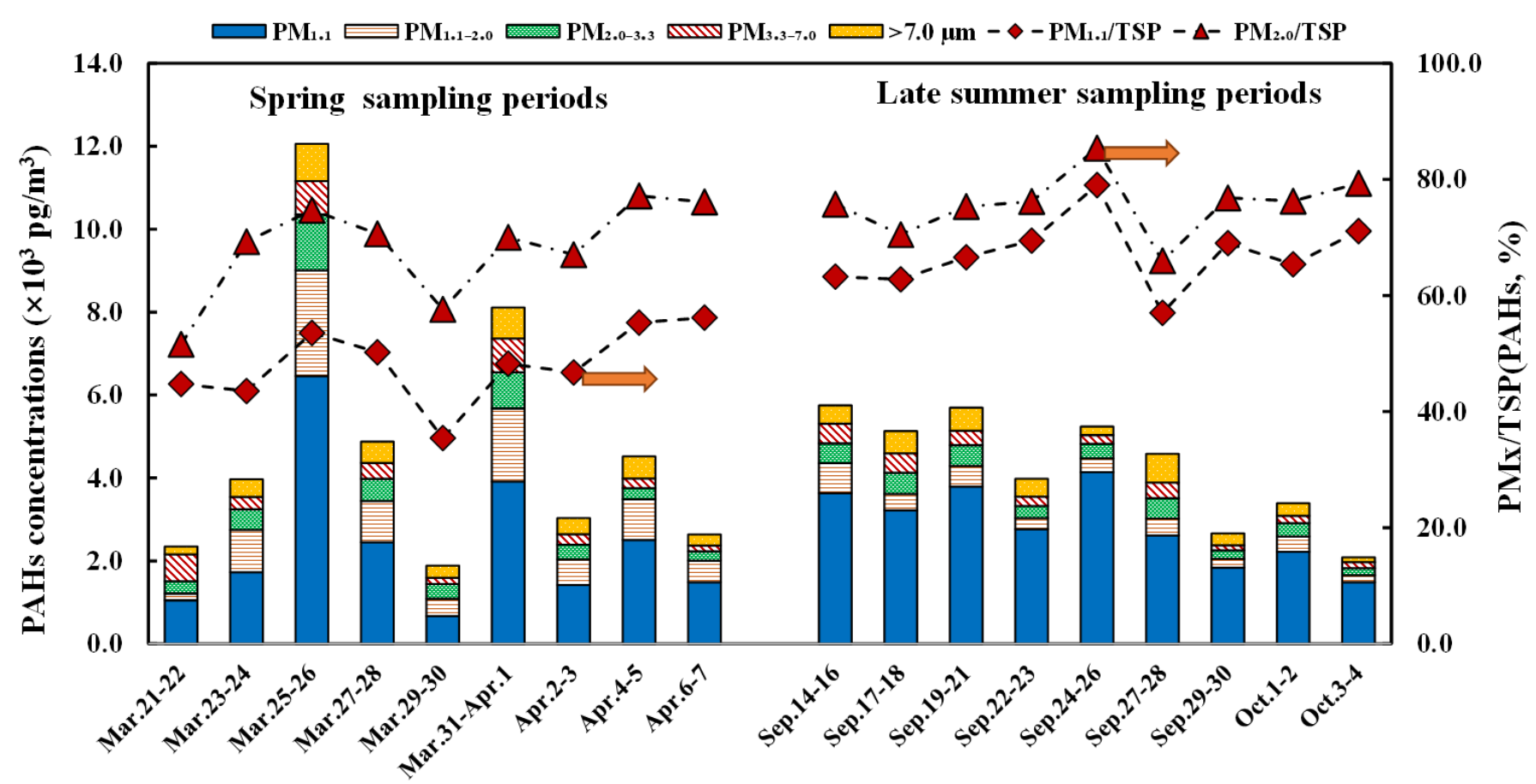

Figure 2. PAHs size distribution at each sampling case during the spring and late summer sampling periods.

Synchronously, several studies have been undertaken to identify the PAHs in different seasons, as shown in Table 2. Dayana found that 16 PAH levels in $\mathrm{PM}_{1.0}$ in the summer were about half of the levels in winter [5]. The authors studied about 16 PAHs in the $\mathrm{PM}_{2.1}$ of Nanjing during spring and found that their levels were higher than in the summer [36]. Moreover, Wang studied 37 different species of PAHs in the summer of 2015 in Shanghai and found that about 50\% were associated with $\mathrm{PM}_{1.1}$ [6]. Furthermore, Ren measured the PAHs in $\mathrm{PM}_{1.1}$ in two megacities and found that the PAHs of $\mathrm{Xi}^{\prime}$ an in the summer were $1 / 10$ of the levels in winter: About $33 \mathrm{ng} / \mathrm{m}^{3}$ in winter and $3.4 \mathrm{ng} / \mathrm{m}^{3}$ in the summer. In addition, the summer levels in the $\mathrm{PM}_{1.1}$ of Guangzhou were half of the levels in winter [28]. Moreover, the PAHs in this article were dominant in $\mathrm{PM}_{1.1}$, which seems very consistent with those reported from numerous articles. However, particular attention should be given to the levels of PAHs in late summer, as they are higher than in spring.

Table 2. PAHs concentrations in particulate samples in the previous studies.

\begin{tabular}{|c|c|c|c|c|c|c|}
\hline \multirow{2}{*}{ City } & \multirow{2}{*}{ Site Description } & \multirow{2}{*}{ Year } & \multirow{2}{*}{ Sample Matrix } & \multicolumn{2}{|c|}{16 PAHs ng/m ${ }^{3}$} & \multirow{2}{*}{ Ref. } \\
\hline & & & & Summer & Other & \\
\hline \multirow{2}{*}{ Shanghai } & \multirow{2}{*}{ Urban/industrial } & \multirow{2}{*}{2017} & PM1.1 & 2.86 (13 PAHs) & 2.41 spring & This study \\
\hline & & & TSP & 4.28 & 4.83 & This study \\
\hline Canoas & Roadside/traffic & 2011 2013 & PM1.0 & 1.32 & 2.02 winter & D.M. (2014) [36] \\
\hline Sapucaia do Sul & $\begin{array}{c}\text { Urban } \\
\text { road/traffic }\end{array}$ & 2011 2013 & PM1.0 & 1.57 & 3.05 winter & D.M. (2014) \\
\hline Shanghai & Suburban & 2015 & PM1.1 & 4.97 (37 PAHS) & & Wang (2016) [6] \\
\hline \multirow{2}{*}{ Nanjing } & Suburban & \multirow{2}{*}{ 2009 2010 } & PM2.1 & 30.76 & 43.5 spring & HE 2014 [37] \\
\hline & Urban & & PM2.1 & 25.92 & 56.92 spring & HE 2014 \\
\hline \multirow{2}{*}{ Xi'an } & \multirow{2}{*}{ Urban } & \multirow{2}{*}{2013} & PM1.1 & 3.4 & 33 winter & Ren 2017 [28] \\
\hline & & & TSP & 6 & 57 winter & Ren 2017 \\
\hline \multirow{2}{*}{ Guangzhou } & \multirow{2}{*}{ Urban } & \multirow{2}{*}{2013} & PM1.1 & 2.2 & 4.4 winter & Ren 2017 \\
\hline & & & TSP & 2.8 & 18 winter & Ren 2017 \\
\hline
\end{tabular}


Based on the PAH molecular weight, these PAHs could be divided into three groups [6,38,39]: FL, PHE, and ANT. In this case, 2- and 3-ring PAHs could be classified as Low Molecular Weight (LMW) PAHs; FLA, PYR, CHR, and BaA with 4-ring PAHs could be defined as Middle Molecular Weight (MMW); while BbF, BkF, BaP, IcdP, DahA, and BghiP with 5-and 6-ring PAHs are always defined as High Molecular Weight (HMW) PAHs. Generally, LMW PAHs are usually considered to have formed during low temperature processes (such as biomass burning), while HMW PAHs are emitted from relatively megathermal reactions, such as fuel combustion, which react to form stable PAHs during pyrosynthesis. These PAHs are less alkylated and they easily contain more aromatic rings [38,39]. Based on Table 3, LMW PAH distributions in spring were $25.9 \%$ in $\mathrm{PM}_{1.1}$, $19.0 \%$ in $\mathrm{PM}_{1.1-2.0}, 18.3 \%$ in $\mathrm{PM}_{2.0-3.3}, 19.8 \%$ in $\mathrm{PM}_{3.3-7.0}$, and $17.1 \%$ in coarse particles $>7 \mu \mathrm{m}$. LMW PAHs in late summer were $46.9 \%$ in $\mathrm{PM}_{1.1}, 11.9 \%$ in $\mathrm{PM}_{1.1-2.0}, 13.8 \%$ in $\mathrm{PM}_{2.0-3.3}, 11.5 \%$ in $\mathrm{PM}_{3.3-7.0}$, and $15.9 \%$ in coarse particles ( $\left.>7 \mu \mathrm{m}\right)$. With the similarity with LMW PAHs in TSP, it could be seen that LMW PAHs in late summer were mainly found in the fine particles of $\mathrm{PM}_{1.1}$.

Table 3. Average concentration and percentage of LMW, MMW, HMW, COMPAHs, and CANPAHs in five-range ambient particles during the sampling and late summer sampling periods.

\begin{tabular}{|c|c|c|c|c|c|c|c|c|c|c|c|c|}
\hline & & \multicolumn{6}{|c|}{ Concentrations $\left(\mathrm{pg} / \mathrm{m}^{3}\right)$} & \multicolumn{5}{|c|}{ PM/TSP (\%) } \\
\hline & & PM1.1 & $\begin{array}{c}\text { PM1.1- } \\
2.0\end{array}$ & $\begin{array}{c}\text { PM2.0- } \\
3.3\end{array}$ & $\begin{array}{c}\text { PM3.3- } \\
7.0\end{array}$ & $\begin{array}{l}>7.0 \\
\mu \mathrm{m}\end{array}$ & TSP & PM1.1 & $\begin{array}{c}\text { PM1.1- } \\
2.0\end{array}$ & $\begin{array}{c}\text { PM2.0- } \\
3.3\end{array}$ & $\begin{array}{c}\text { PM3.3- } \\
7.0\end{array}$ & $\begin{array}{l}>7.0 \\
\mu \mathrm{m}\end{array}$ \\
\hline \multirow{6}{*}{$\begin{array}{l}\text { Spring } \\
\text { AVG. }\end{array}$} & LMW & 95.0 & 69.5 & 66.9 & 72.4 & 62.7 & 366.3 & 25.9 & 19.0 & 18.3 & 19.8 & 17.1 \\
\hline & MMW & 810.9 & 392.0 & 224.9 & 187.0 & 225.9 & 1840.6 & 44.1 & 21.3 & 12.2 & 10.2 & 12.3 \\
\hline & HMW & 1502.1 & 542.5 & 235.7 & 153.9 & 185.7 & 2619.9 & 57.3 & 20.7 & 9.00 & 5.87 & 7.09 \\
\hline & TPAHs & 2407.9 & 1004.0 & 527.4 & 413.3 & 474.2 & 4826.8 & 49.9 & 20.8 & 10.9 & 8.56 & 9.82 \\
\hline & COMPAHs & 2198.0 & 889.3 & 438.9 & 348.9 & 385.1 & 4260.3 & 51.6 & 20.9 & 10.3 & 8.19 & 9.04 \\
\hline & CANPAHs & 1608.2 & 604.9 & 285.8 & 199.8 & 240.1 & 2938.8 & 54.7 & 20.6 & 9.73 & 6.80 & 8.17 \\
\hline \multirow{6}{*}{$\begin{array}{l}\text { Late } \\
\text { sum- } \\
\text { mer } \\
\text { AVG. }\end{array}$} & LMW & 144.7 & 36.6 & 42.6 & 35.3 & 49.1 & 308.2 & 46.9 & 11.9 & 13.8 & 11.4 & 15.9 \\
\hline & MMW & 1072.3 & 118.8 & 124.8 & 114.9 & 159.8 & 1590.6 & 67.4 & 7.469 & 7.846 & 7.225 & 10.0 \\
\hline & HMW & 1638.7 & 219.5 & 203.1 & 131.1 & 188.2 & 2380.5 & 68.8 & 9.22 & 8.53 & 5.51 & 7.91 \\
\hline & TPAHs & 2855.6 & 374.8 & 370.5 & 281.3 & 397.1 & 4279.3 & 66.7 & 8.76 & 8.66 & 6.57 & 9.28 \\
\hline & COMPAHs & 2442.0 & 328.2 & 306.5 & 235.5 & 329.7 & 3642.1 & 67.0 & 9.01 & 8.42 & 6.47 & 9.05 \\
\hline & CANPAHs & 2118.7 & 242.8 & 242.3 & 180.2 & 232.3 & 3016.3 & 70.2 & 8.05 & 8.03 & 5.97 & 7.70 \\
\hline
\end{tabular}

The MMW PAH levels in TSP were about 5 times higher than the LMW PAHs in the two sampling periods. The MMW PAH levels in spring were $44.1 \%$ in $\mathrm{PM}_{1.1}, 21.3 \%$ in $\mathrm{PM}_{1.1-2.0}, 12.2 \%$ in $\mathrm{PM}_{2.0-3.3}, 10.2 \%$ in $\mathrm{PM}_{3.3-7.0}$, and $12.3 \%$ in coarse particles $(>7 \mu \mathrm{m})$. The MMW PAH levels in late summer were about $67.4 \%$ in $\mathrm{PM}_{1.1}$ and $10.1 \%$ in coarse particles $(>7 \mu \mathrm{m})$. These results showed that the MMW PAHs are more concentrated in the fine particles $\left(\mathrm{PM}_{1.1}, \mathrm{PM}_{1.1-2.0}\right)$ than the LMW PAHs. The HMW PAHs were about 8 times higher than the LMW PAHs and about 1.5 times higher in both spring and late summer. The size distributions of MMW PAHs were 57.3\% in $\mathrm{PM}_{1.1}$ and $20.7 \%$ in $\mathrm{PM}_{1.1-2.0}$ in spring, as well as $68.8 \%$ in $\mathrm{PM}_{1.1}$ and $9.22 \%$ in $\mathrm{PM}_{1.1-2.0}$ in late summer. The HMW PAHs almost always remain in fine particles, which could be explained by their non-volatile characteristics $[5,6,8]$. Although the TPAHs in the TSP of spring were higher than in late summer, the TPAH levels in the $\mathrm{PM}_{1.1}$ of late summer were also higher for the HMW, LMW, and MMW groups. Compared with the levels in spring, PAHs were more likely to concentrate in $\mathrm{PM}_{1.1}$ during late summer.

In addition, a Combustion-Derived PAHs group (COMPAHs) has been classified to include FL, PYR, BaA, CHR, BbF, BkF, BaP, IcdP, and BghiP [1,40]. COMPAHs/TPAHs are characteristic PAH diagnostic parameters for producing the stationary sources. When this value is near 1.00 , this points to the dominant combustion source $[37,41]$. As shown in Table 3, the COMPAH levels in TSP in spring were high at $4260.4 \mathrm{pg} / \mathrm{m}^{3}$ and the COM$\mathrm{PAH} / \mathrm{TPAH}$ was 0.88 . The COMPAH levels in the TSP of late summer were $3642.1 \mathrm{pg} / \mathrm{m}^{3}$, which accounts for $85.1 \%$ of TPAHs and $67.1 \%$ are in $\mathrm{PM}_{1.1}$. The COMPAHs/TPAHs values in spring (0.88) and late summer (0.85) showed that the combustion source was indeed a major PAH source. Carcinogenic PAHs (CANPAHs) are defined to assess the carcinogenic potential of PAHs in exposed people and usually include $\mathrm{BaA}, \mathrm{CHR}, \mathrm{BkF}, \mathrm{BaP}$, IcdP, and 
DahA $[32,41]$. The results presented in Table 3 show that the CANPAHs in spring were mainly located in $\mathrm{PM}_{1.1}$ and $\mathrm{PM}_{1.1-2.0}$. CANPAHs in late summer were $70.2 \%$ located in $\mathrm{PM}_{1.1}$, showing that the CANPAHs were generally mainly located in $\mathrm{PM}_{1.1}$. In general, CANPAHs and COMPAHs were mainly distributed in $\mathrm{PM}_{1.1}$ and $\mathrm{PM}_{1.1-2.0}$, respectively. Furthermore, CANPAHs belong to the COMPAHs group, which indicates the possibility that combustion emissions might show the health risks.

\subsection{Possible Anthropogenic Source Apportionment of PAHs in $P M_{1.1}$}

The LMW/HMW PAH ratio could be used to distinguish pyrogenic from petrogenic sources. When the ratio is over 1.00, this could indicate that the main source might be petrogenic, and if the ratio is below 1.00 , the main source might be pyrogenic $[6,12,38]$. Here, a lower LMW/HMW ratio and higher COMPAHs/TPAHs ratios in TSP (Table 3) during the two sampling periods indicated that the combustion sources might play an important role in PAH generation. This is supported by the negative correlation between LMW/HMW and COMPAHs (spring, $\mathrm{r}=-0.54$; late summer, $\mathrm{r}=-0.36$ ) and the positive correlation between COMPAHs and TPAHs (spring, $r=1.00$; late summer, $r=0.996$ ). Therefore, combustion sources could be thought of as the dominant PAH source in the Baoshan sampling area.

On the contrary, the PAH diagnosis ratio method is used to identify the source of PAHs by the frequently found PAH ratio. The typical PAH isomer pair ratios are shown in Table $1[38,42,43]$. Considering the size distribution of the PAHs, the PAH ratios in $\mathrm{PM}_{1.1}$ and TSP were observed and shown in Figure 3. In the spring, the values of $\mathrm{BaA} /(\mathrm{BaA}+\mathrm{CHR})$ in $\mathrm{PM}_{1.1}$ and TSP varied from 0.107 to 0.241 , revealing that the main source was petrogenic. The values of IcdP/(IcdP+BghiP) in $\mathrm{PM}_{1.1}$ and TSP were between 0.4 and 0.5 , indicating that the dominant petroleum combustion source, Bap/BghiP, was close to 0.60 , which shows the traffic emissions effects, especially for diesel vehicles. The values of FLA/(FLA+PYR) were about 0.30 to 0.60 , showing the main fossil fuel combustion sources with some effects from biomass coal combustion and petrogenic sources. In summary, it could be considered that the source of PAHs in $\mathrm{PM}_{1.1}$ and TSP was mainly traffic emissions. This observation is consistent with the ionic and elemental source analysis [24]. In late summer, the values of $\mathrm{BaA} /(\mathrm{BaA}+\mathrm{CHR})$ in $\mathrm{PM}_{1.1}$ and TSP were between 0.20 to 0.35 , which showed that the key coal combustion levels of IcdP/(IcdP+BghiP) were mostly close to $0.4 \sim 0.5$, indicating the effect of petroleum combustion. The Bap/BghiP ratio showed both the traffic and non-traffic emissions. Compared with spring, the PAH source varied to several sources in late summer.
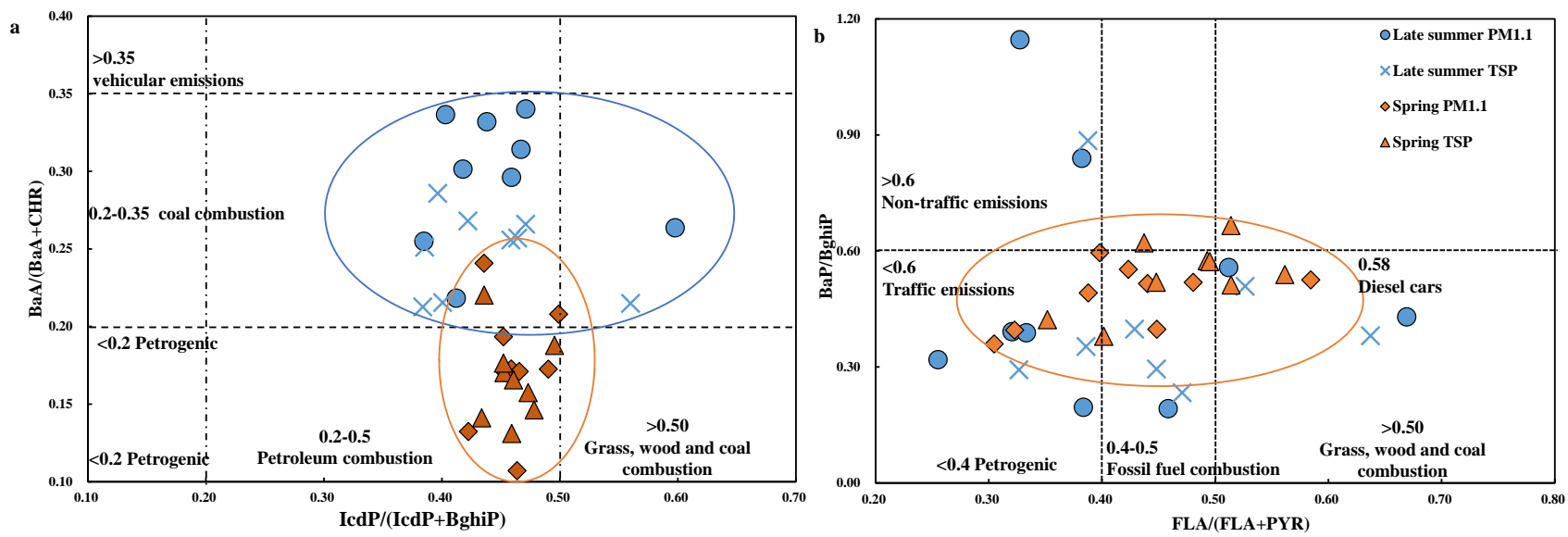

Figure 3. Diagnostics ratio cross plotting in $\mathrm{PM}_{1.1}$ and TSP, (a) IcdP/(IcdP+BghiP) and BaA/(BaA+CHR), (b) FLA/ (FLA+PYR) and BaP/BghiP.

Due to the main $\mathrm{PM}_{1.1}$ distribution, the Principal Component Analysis (PCA), shown in Table 4, is presented with three and four factors in $\mathrm{PM}_{1.1}$, explaining $96.9 \%$ and $88.3 \%$ of 
the data variance during the spring and late summer sampling periods. In spring, Fator 1 explained $62.8 \%$ of the total variance and was highly loaded with $\mathrm{BaA}, \mathrm{BaP}, \mathrm{CHR}$, BghiP, BkF, PHE, FLA, and ANT, which almost belonged to HMW PAHs. BaA and BaP could be used as stationary source indicators, such as the steel industry, and CHR, FLA, and PHE are the indicators of diesel vehicle emissions [44]. Therefore, this factor could indicate industry sources and diesel vehicle emissions [44,45]. Factor 2 explained $18.6 \%$ of the total variance and was highly loaded with DahA (factor loading $>0.928$ ), serving as a tracer for gasoline exhaust $[44,46,47]$. Therefore, Factor 2 was associated with gasoline vehicle emissions. Factor 3 explained $15.6 \%$ of the total variance and was highly loaded with PYR and FLA (factor loading $>0.60$ ), and PYR has been used as a tracer for roadside soil particle and combustion sources. In late summer, the stationary sources and diesel vehicle emission (35.6\%), biomass and coal combustion (25.2\%), gasoline vehicle emissions $(18.0 \%)$, and roadside soil particles are mainly responsible for the PAHs in $\mathrm{PM}_{1.1}$. Both in spring and late summer, the main sources were stationary (e.g., the steel industry) and diesel vehicle emissions, and the Baowu steel group was within close proximity. Generally, local activities showed more variable effects on PAHs in late summer than in spring.

Table 4. PCA loading factors for $\mathrm{PAH}$ compounds in fine particles of $\mathrm{PM}_{1.1}$ during the spring and late summer sampling periods.

\begin{tabular}{|c|c|c|c|c|c|c|c|}
\hline \multirow{2}{*}{ PAHs } & \multicolumn{3}{|c|}{ Spring } & \multicolumn{4}{|c|}{ Late Summer } \\
\hline & F 1 & F2 & F3 & F1 & F2 & F3 & F4 \\
\hline $\mathrm{BaA}$ & 0.950 & 0.204 & 0.223 & 0.879 & 0.113 & 0.333 & 0.239 \\
\hline $\mathrm{BaP}$ & 0.938 & 0.264 & 0.213 & 0.037 & 0.870 & 0.446 & 0.169 \\
\hline CHR & 0.925 & 0.270 & 0.255 & 0.771 & 0.176 & 0.254 & 0.312 \\
\hline BghiP & 0.918 & 0.366 & 0.144 & 0.944 & -0.013 & -0.212 & 0.095 \\
\hline BkF & 0.877 & 0.408 & 0.248 & -0.200 & 0.835 & -0.310 & 0.291 \\
\hline IcdP & 0.868 & 0.426 & 0.249 & 0.731 & 0.506 & -0.008 & -0.108 \\
\hline $\mathrm{BbF}$ & 0.864 & 0.409 & 0.279 & 0.378 & 0.857 & 0.002 & 0.256 \\
\hline PHE & 0.849 & 0.361 & 0.376 & 0.825 & 0.357 & 0.212 & 0.320 \\
\hline FLA & 0.787 & 0.001 & 0.605 & 0.196 & 0.312 & -0.049 & 0.865 \\
\hline ANT & 0.758 & 0.161 & 0.481 & 0.865 & -0.118 & -0.002 & -0.134 \\
\hline DahA & 0.232 & 0.928 & 0.222 & 0.144 & 0.169 & 0.932 & 0.030 \\
\hline FL & 0.626 & 0.661 & 0.227 & 0.317 & 0.328 & 0.783 & 0.002 \\
\hline PYR & 0.233 & 0.359 & 0.895 & 0.261 & 0.641 & 0.551 & -0.030 \\
\hline Variance (\%) & 62.8 & 18.6 & 15.6 & 35.6 & 25.2 & 18.0 & 9.41 \\
\hline Sources & $\begin{array}{l}\text { industrial } \\
\text { emissions, } \\
\text { diesel } \\
\text { vehicle } \\
\text { emissions }\end{array}$ & $\begin{array}{l}\text { gasoline } \\
\text { vehicle } \\
\text { emissions }\end{array}$ & $\begin{array}{c}\text { coal } \\
\text { combustion, } \\
\text { roadside soil } \\
\text { particle }\end{array}$ & $\begin{array}{l}\text { stationary } \\
\text { sources, } \\
\text { diesel } \\
\text { vehicle } \\
\text { emissions }\end{array}$ & $\begin{array}{c}\text { biomass and } \\
\text { coal } \\
\text { combustion }\end{array}$ & $\begin{array}{l}\text { gasoline } \\
\text { vehicle } \\
\text { emissions }\end{array}$ & $\begin{array}{l}\text { roadside soil } \\
\text { particle }\end{array}$ \\
\hline
\end{tabular}

To discover the air mass transport patterns and impacts, the Wind Direction (WD) frequency during the sampling periods is shown in Figure 4a. The wind in the spring came mainly from the North (N), East (E), and West (W), while it came mainly from the East (E) and Northeast (NE) during the late summer period. The air mass backward trajectories in the sampling sites are shown in Figure $4 b$, which are the four representative sampling cases selected, such as 25-26 March (largest TPAH levels in spring), 29-30 March (the lightest one), 14-16 September (the heaviest one in late summer), and 3-4 October (the lightest one). The air masses on 25-26 March were across the northwest part of China to Shanghai, which is mainly a coal combustion area, and the pollutants could affect Shanghai through the air mass long distance transport to cause a sudden pollutant increase [6,27]. The 29-30 March case showed that the air masses came from the marine area in the northeast, which could play a cleaning role in atmospheric contamination. Air masses in the 14-16 September case showed that they came from the Korean area across the water to Shanghai. The 3-4 October case showed that the air masses came from the northern part of China across the marine 
area to Shanghai. Additionally, the air mass frequencies showed that the northern part of the sampling site made a non-negligible contribution. There are plenty of steel-related industries as well as several ports and mounts of transport vehicles and steamships, which indicate that the stationary sources are the main sources of pollution. Moreover, the air condition in spring could lead to more long-range transport of air masses with species pollutants, which could be an important factor in explaining the occurrence of the relatively severe air pollution events. Considering the main anthropogenic sources and assembled CANPAHs in fine particles is an important factor to evaluate the health risks of PAHs.

a

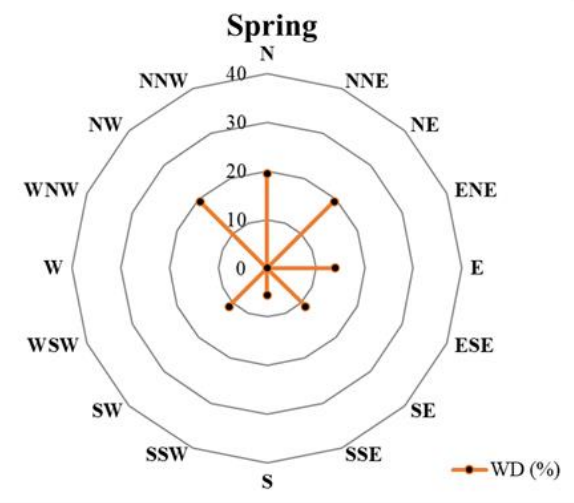

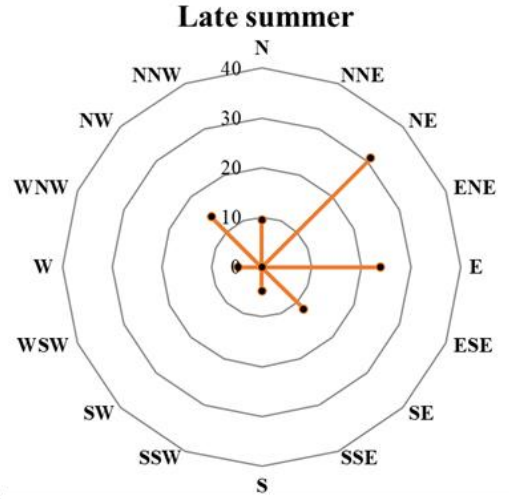

b

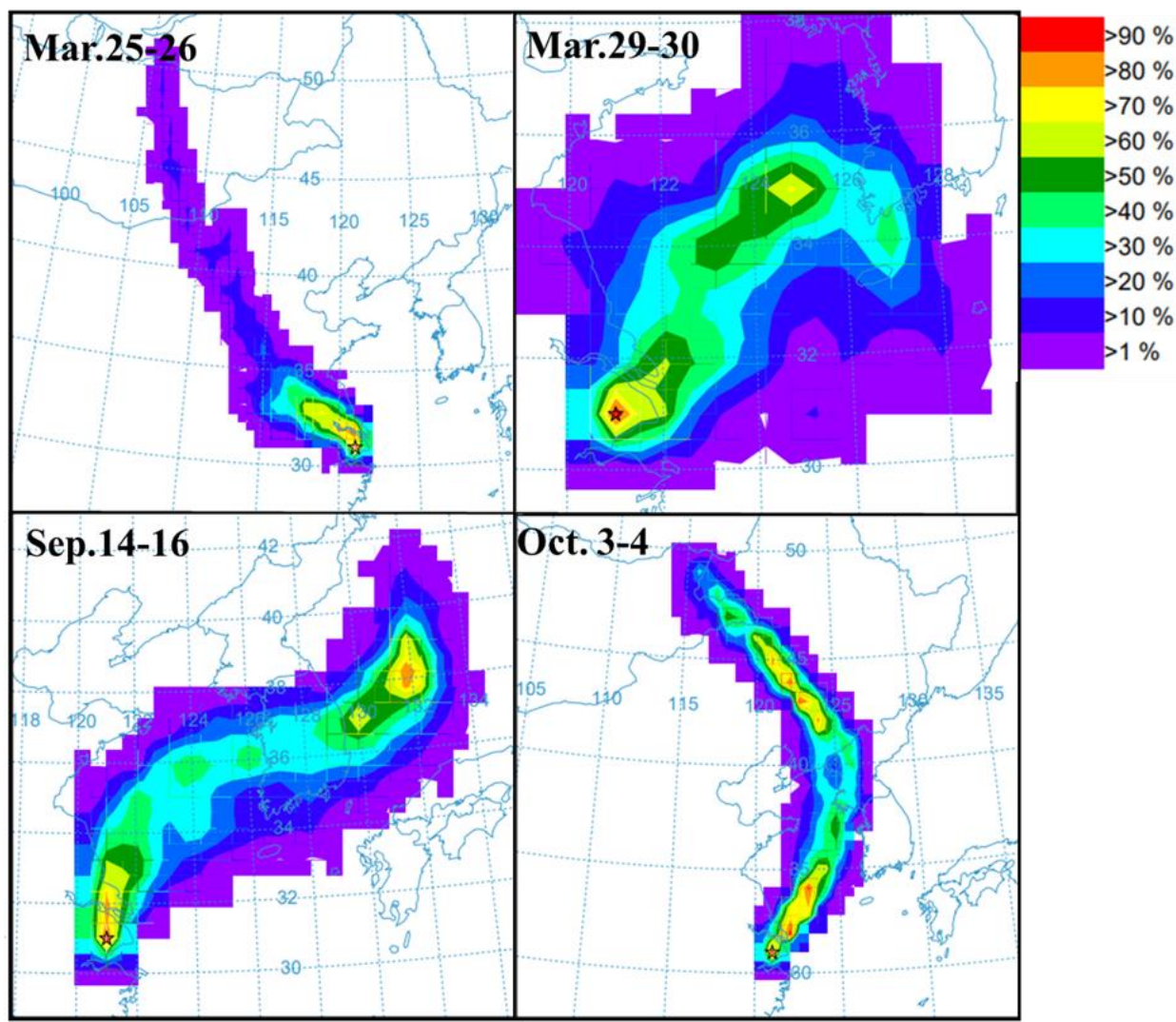

Figure 4. (a) Wind direction frequency $(\mathrm{WD} \%)$ in the spring and late summer sampling periods $(\mathrm{N}$ : North; S: South; E: East; W: West); (b) air mass backward trajectories at the four sampling cases, 25-26 March; 29-30 March; 14-16 September; 3-4 October.

\subsection{Carcinogenic Risk and Mutagenicity of PAHs in $P M_{1.1}$ and $P M_{2.0}$}

About $40 \%$ of the $\mathrm{PM}_{2.5}$ content is organic matter, which might be carcinogenic and mutagenic [48-51]. These PAHs are considered to pose a high risk to human health among the atmospheric trace chemical substances [38]. PAHs could cause adverse respiratory 
effects in humans [52] with mutagenic and carcinogenic consequences [2]. Here, the PAH health risk analysis was based on the model assessment of carcinogenic risk associated with exposure to PAHs by the inhalation pathway. Additionally, there are six age-group analysis results shown in Figure 5. The Level of Carcinogenic Risk (ILCR) of TSP among all of the six age groups were over $1 \times 10^{-6}$ in both the spring and late summer periods. However, the levels in spring were higher than in the late summer. For the size distribution, PAHs in $\mathrm{PM}_{1.1}$ were shown as the principal contributors to this carcinogenic risk, especially for the birth to age 1,1 to 6 , and 6-16 age groups, which are considered the children and young age group. The ILCR values in $\mathrm{PM}_{1.1}$ were higher than $1 \times 10^{-6}$, indicating high risks. On the contrary, the ILCR showed the risk from PAHs in both $\mathrm{PM}_{1.1}$ and $\mathrm{PM}_{1.1-2.0}$ in spring, and only $\mathrm{PM}_{1.1}$ in late summer. This could be explained by the PAHs that were mainly found in $\mathrm{PM}_{1.1}$ during the late summer.

$\mathbf{a}$

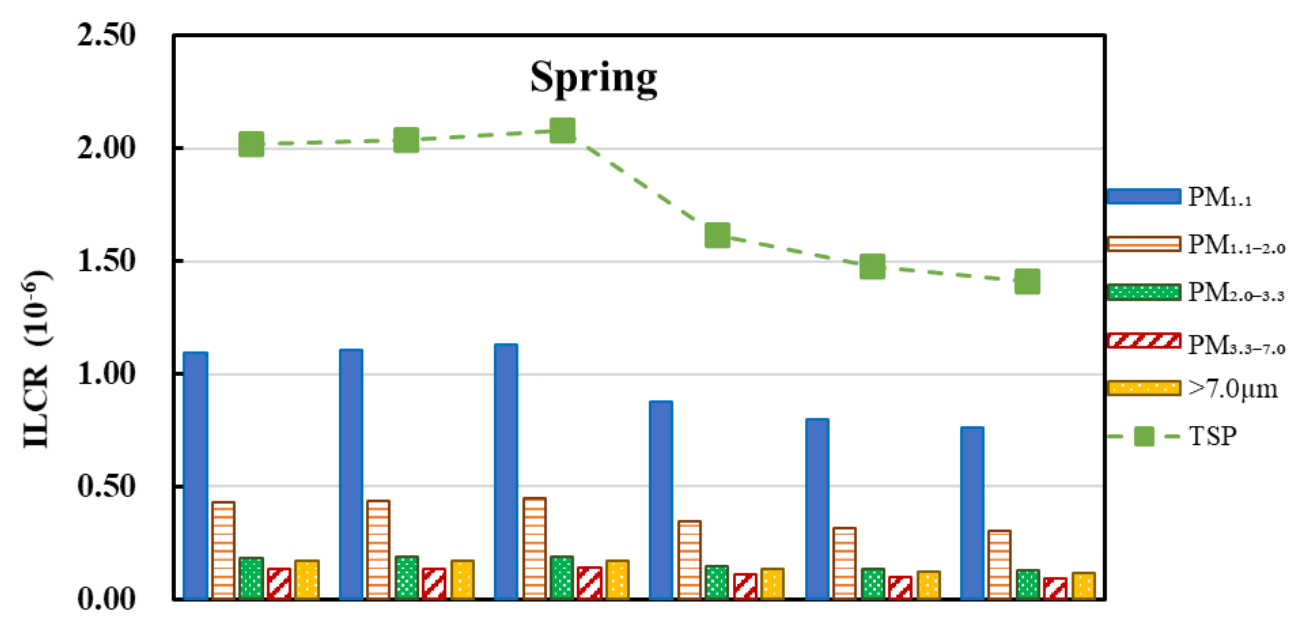

b

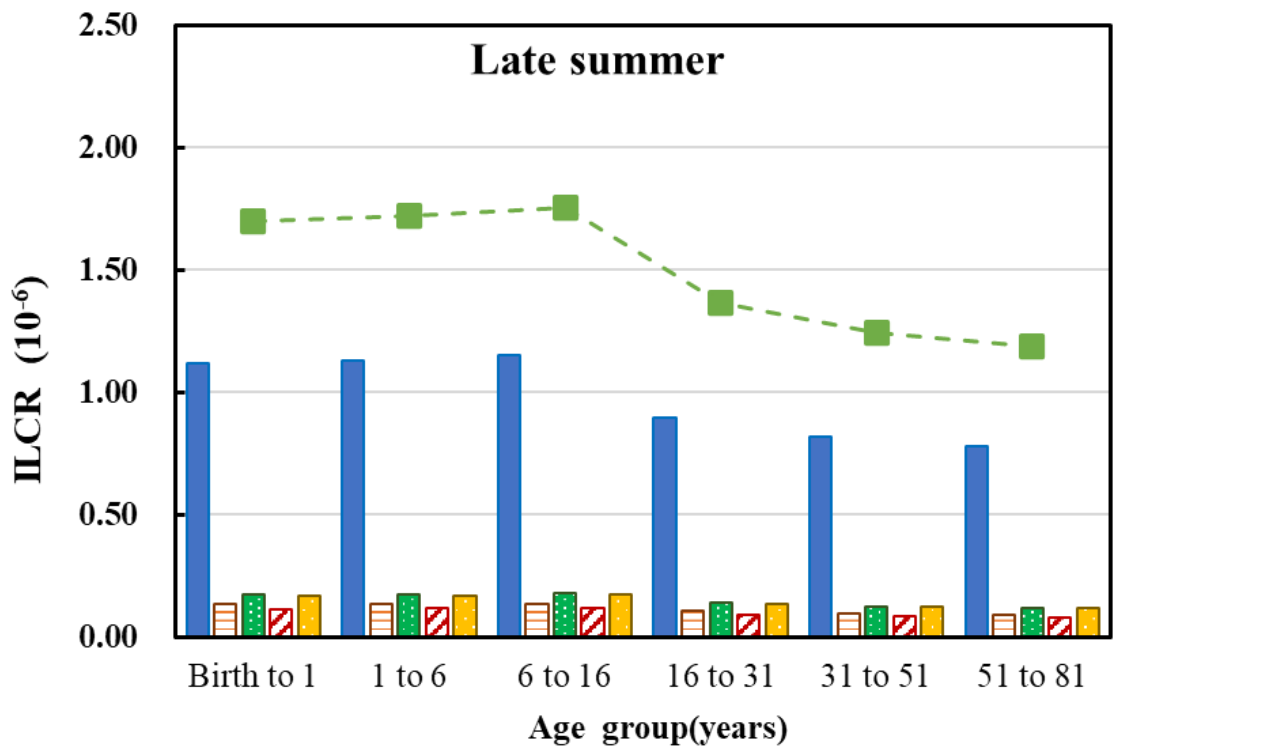

Figure 5. The ILCR values in five particles during the spring (a) and late summer (b) sampling periods.

According to TEQ (BaP), the total $\mathrm{BaP}$ measured in TSP during the spring and late summer was still below the WHO standard $\left(1 \mathrm{ng} / \mathrm{m}^{3}\right)$. However, the total BaP measured in TSP on the 25-26 March sampling event was higher than this standard. BaP, BbF, and IcdP were the main contributors, especially BaP. Additionally, the results showed that not only BaP, but also BbF and IcdPm which belong to the HMW PAHs, and BaA made high contributions to ILCR in late summer. Moreover, this result is consistent with several published articles $[5,9,28]$. These PAHs with higher health risks belong to HMW PAHs and the COMPAHs group. It might be the case that CANPAHs are associated with airborne 
particles rather than the gas phase, especially fine particles $[9,24]$. The relative contribution levels of $\mathrm{BaP}, \mathrm{BbF}$, IndP, and $\mathrm{BaA}$ to $\mathrm{BaPeq}$ showed the low concentrations of the pollutants in air, but they can still pose serious health risks. On the contrary, due to the limited chemical interactions and other parameters, more work is required regarding the health risk analysis in this area.

\section{Conclusions}

Particle-bound PAHs in the ambient Baoshan area of Shanghai were first measured for their chemical characterization, possible sources, and toxic evaluation during the spring and late summer. The chemical analysis indicated that PAHs had higher accumulation efficiency in fine particles of $\mathrm{PM}_{1.1}$, especially in the late summer. More research is required to fully understand the conditions of PAH accumulation efficiency, the influence of meteorological factors and sunlight, as well as the photochemical degradation of PAHs. Diagnostic ratios, PCA analysis, and air mass backward trajectories showed that local stationary sources (e.g., the steel industry and the relative transportations) are key PAH sources. PAHs in the late summer tended to associate with $\mathrm{PM}_{1.1}$, which could be explained by the effect of temperature and sunlight and some possible chemical responses. The ILCR values from the model assessment of carcinogenic risk by the inhalation pathway indicated that the young and children would have a higher health risk than the other age groups. The higher ILCR values in $\mathrm{PM}_{1.1}$ indicated that toxic PAHs were found in fine particles. However, according to the finer size and large area characteristics of the fine particles, they may pose more serious health effects. Although the PAHs could be cleaned up by the rainy weather, they could maintain relatively high concentrations in finer particles with good air quality. In addition, there are still several tons of PAHs components in the atmosphere, such as Nitro-PAHs and Oxygen-PAHs. Therefore, significant attention should be paid to their serious effects on health. Furthermore, compared with the particles' mass concentration, particular attention should be paid to these PAHs, trace elements, and other compounds to improve the environmental conditions.

Supplementary Materials: The following are available online at https:/ / www.mdpi.com/article/10 .3390/pr9112016/s1. Table S1: Meteorological factors in the Baoshan area of Shanghai during the spring and early autumn sampling periods. Table S2: PAHs concentrations in five-size range particles during the spring and late summer sampling periods. Table S3: Pearson's correlation matrix between the PAHs, PM, meteorological factors, and other contaminations. Figure S1: Air quality factors on each day during the sampling periods: A, spring; B, late summer.

Author Contributions: Conceptualization, W.W. and Q.W.; methodology, W.W. and D.N.; software, W.W. and D.N.; validation, W.W., F.L. and S.L.; formal analysis, F.L. and M.S.; investigation, W.W., K.X. and S.L.; resources, S.L.; data curation, W.W.; writing-original draft preparation, W.W.; writingreview and editing, W.W., M.S., K.X. and T.C.; visualization, W.W.; supervision, Q.W.; project administration, W.W.; funding acquisition, Q.W. All authors have read and agreed to the published version of the manuscript.

Funding: This study was partially supported by the Special Funds for Innovative Area Research (No. 20120015, FY 2008-FY2012) and Basic Research (B) (No. 24310005, FY2012-FY2014; No. 18H03384, FY2017 FY2020) of Grant-in-Aid for Scientific Research of Japanese Ministry of Education, Culture, Sports, Science and Technology (MEXT), and the Steel Foundation for Environmental Protection Technology of Japan (No. C-33, FY 2015-FY 2017).

Acknowledgments: We would like to express our gratitude to the master students in the LU lab in Shanghai University for their help in our sampling work.

Conflicts of Interest: The authors declare no conflict of interest. 


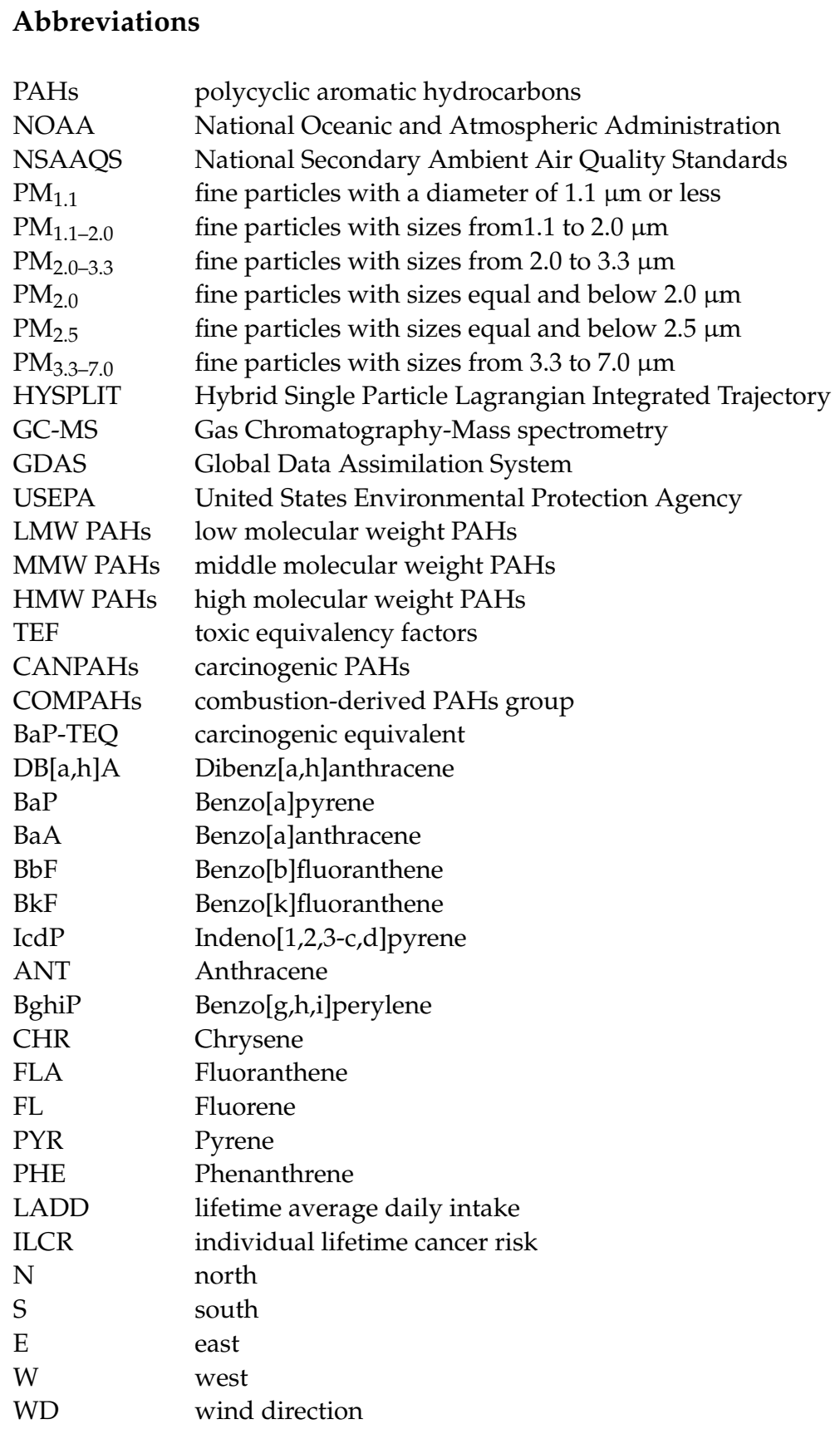

\section{References}

1. Vu-Duc, N.; Phung Thi, L.A.; Le-Minh, T.; Nguyen, L.A.; Nguyen-Thi, H.; Pham-Thi, L.H.; Doan-Thi, V.A.; Le-Quang, H.; Nguyen-Xuan, H.; Thi Nguyen, T.; et al. Analysis of Polycyclic Aromatic Hydrocarbon in Airborne Particulate Matter Samples by Gas Chromatography in Combination with Tandem Mass Spectrometry (GC-MS/MS). J. Anal. Methods Chem. 2021, 2021, 6641326. [CrossRef] [PubMed]

2. $\quad$ Alves, C.A.; Vicente, A.M.; Custódio, D.; Cerqueira, M.; Nunes, T.; Pio, C.; Lucarelli, F.; Calzolai, G.; Nava, S.; Diapouli, E.; et al. Polycyclic aromatic hydrocarbons and their derivatives (nitro-PAHs, oxygenated PAHs, and azaarenes) in PM2.5 from Southern European cities. Sci. Total Environ. 2017, 595, 494-504. [CrossRef] [PubMed]

3. Abdel-Shafy, H.I.; Mansour, M.S.M. A review on polycyclic aromatic hydrocarbons: Source, environmental impact, effect on human health and remediation. Egypt. J. Pet. 2016, 25, 107-123. [CrossRef]

4. Khan, A.; Ishaq, M.; Khan, M.A. Effect of vehicle exhaust on the quantity of polycyclic aromatic hydrocarbons (PAHs) in soil. Environ. Monit. Assess. 2008, 137, 363-369. [CrossRef] [PubMed]

5. Agudelo-Castañeda, D.M.; Teixeira, E.C. Seasonal changes, identification and source apportionment of PAH in PM1.0. Atmos. Environ. 2014, 96, 186-200. [CrossRef] 
6. Wang, Q.; Kobayashi, K.; Lu, S.; Nakajima, D.; Wang, W.; Zhang, W.; Sekiguchi, K.; Terasaki, M. Studies on size distribution and health risk of 37 species of polycyclic aromatic hydrocarbons associated with fine particulate matter collected in the atmosphere of a suburban area of Shanghai city, China. Environ. Pollut. 2016, 214, 149-160. [CrossRef] [PubMed]

7. Wang, Z.; Ren, P.; Sun, Y.; Ma, X.; Liu, X.; Na, G.; Yao, Z. Gas/particle partitioning of polycyclic aromatic hydrocarbons in coastal atmosphere of the north Yellow Sea, China. Environ. Sci. Pollut. Res. 2013, 20, 5753-5763. [CrossRef]

8. Hassanien, M.A.; Abdel-Latif, N.M. Polycyclic aromatic hydrocarbons in road dust over Greater Cairo, Egypt. J. Hazard. Mater. 2008, 151, 247-254. [CrossRef]

9. Agudelo-Castañeda, D.; Teixeira, E.; Schneider, I.; Lara, S.R.; Silva, L.F.O. Exposure to polycyclic aromatic hydrocarbons in atmospheric PM1.0 of urban environments: Carcinogenic and mutagenic respiratory health risk by age groups. Environ. Pollut. 2017, 224, 158-170. [CrossRef]

10. Kozáková, J.; Leoni, C.; Klán, M.; Hovorka, J.; Racek, M.; Koštejn, M.; Ondráček, J.; Moravec, P.; Schwarz, J. Chemical characterization of PM1-2.5 and its associations with PM1, PM2.5-10 and meteorology in urban and suburban environments. Aerosol Air Qual. Res. 2018, 18, 1684-1697. [CrossRef]

11. Zhang, Y.; Tao, S. Global atmospheric emission inventory of polycyclic aromatic hydrocarbons (PAHs) for 2004. Atmos. Environ. 2009, 43, 812-819. [CrossRef]

12. Liu, J.; Chen, Y.; Chao, S.; Cao, H.; Zhang, A.; Yang, Y. Emission control priority of PM2.5-bound heavy metals in different seasons: A comprehensive analysis from health risk perspective. Sci. Total Environ. J. 2018, 644, 20-30. [CrossRef]

13. Zhang, F.; Wang, Z.W.; Cheng, H.R.; Lv, X.P.; Gong, W.; Wang, X.M.; Zhang, G. Seasonal variations and chemical characteristics of PM2.5 in Wuhan, central China. Sci. Total Environ. 2015, 518-519, 97-105. [CrossRef]

14. Tao, Y.; Yin, Z.; Ye, X.; Ma, Z.; Chen, J. Size distribution of water-soluble inorganic ions in urban aerosols in Shanghai. Atmos. Pollut. Res. 2014, 5, 639-647. [CrossRef]

15. Ding, X.X.; Kong, L.D.; Du, C.T.; Zhanzakova, A.; Fu, H.B.; Tang, X.F.; Wang, L.; Yang, X.; Chen, J.M.; Cheng, T.T. Characteristics of size-resolved atmospheric inorganic and carbonaceous aerosols in urban Shanghai. Atmos. Environ. 2017, 167, 625-641. [CrossRef]

16. Wu, Z.; Wang, S.; Luo, Z.; Chen, L.; Meng, H.; Zhao, J. Physico-chemical properties and gasification reactivity of co-pyrolysis char from different rank of coal blended with lignocellulosic biomassEffects of the cellulose. Bioresour. Technol. 2017, 235, 256-264. [CrossRef]

17. Huang, Y.; Sun, X.; Liu, M.; Zhu, J.; Yang, J.; Du, W.; Zhang, X.; Gao, D.; Qadeer, A.; Xie, Y.; et al. A multimedia fugacity model to estimate the fate and transport of polycyclic aromatic hydrocarbons (PAHs) in a largely urbanized area, Shanghai, China. Chemosphere 2019, 217, 298-307. [CrossRef]

18. Zhang, Y.; Yang, L.; Gao, Y.; Chen, J.; Li, Y.; Jiang, P.; Zhang, J.; Yu, H.; Wang, W. Comparative study of PAHs in PM1 and PM2.5 at a background site in the north China plain. Aerosol Air Qual. Res. 2019, 19, 2281-2293. [CrossRef]

19. Chen, Y.; Wang, J.; Shi, G.; Sun, X.; Chen, Z.; Xu, S. Human health risk assessment of lead pollution in atmospheric deposition in Baoshan District, Shanghai. Environ. Geochem. Health 2011, 33, 515-523. [CrossRef]

20. Sahanghai Environment Protection Bureau. Shanghai Environmental Bulletin (2017). 2017. Available online: https://sthj.sh.gov. cn/assets/html/110939-02.pdf (accessed on 20 July 2018).

21. Wang, Q.; Liu, M.; Yu, Y.; Du, F.; Wang, X. Black carbon in soils from different land use areas of Shanghai, China: Level, sources and relationship with polycyclic aromatic hydrocarbons. Appl. Geochem. 2014, 47, 36-43. [CrossRef]

22. Raaschou-Nielsen, O.; Andersen, Z.J.; Beelen, R.; Samoli, E.; Stafoggia, M.; Weinmayr, G.; Hoffmann, B.; Fischer, P.; Nieuwenhuijsen, M.J.; Brunekreef, B.; et al. Chemical partitioning of fine particle-bound metals on haze-fog and non-haze-fog days in Nanjing, China and its contribution to human health risks. Atmos. Environ. 2015, 36, 142-150.

23. Wang, Q.; Morita, J.; Gong, X.; Nakamura, S.; Suzuki, M.; Lu, S.; Sekiguchi, K.; Nakajima, T.; Daisuke, N.; Miwa, M. Characterization of the Physical Form of Allergenic Cry $\mathrm{j} 1$ in the Urban Atmosphere and Determination of Cry $\mathrm{j} 1$ Denaturation by Air Pollutants. Asian J. Atmos. Environ. 2012, 6, 33-40. [CrossRef]

24. Chang, K.F.; Fang, G.C.; Chen, J.C.; Wu, Y.S.; Tao, Y.; Mi, S.; Zhou, S.; Wang, S.; Xie, X.; Gulia, S.; et al. Air pollution and hospital admissions for respiratory diseases in Lanzhou, China. Environ. Pollut. 2014, 192, 1171-1179.

25. Wu, M.; Sun, R.; Wang, M.; Liang, H.; Ma, S.; Han, T.; Xia, X.; Ma, J.; Tang, L.; Sun, Y.; et al. Analysis of perfluorinated compounds in human serum from the general population in Shanghai by liquid chromatography-tandem mass spectrometry (LC-MS/MS). Chemosphere 2017, 168, 100-105. [CrossRef]

26. Bulejko, P.; Adamec, V.; Schüllerová, B.; Skeřil, R. Levels, sources, and health risk assessment of polycyclic aromatic hydrocarbons in Brno, Czech Republic: A 5-year study. Environ. Sci. Pollut. Res. 2016, 23, 20462-20473. [CrossRef]

27. Wang, Q.; Wang, W. Size characteristics and health risks of inorganic species in PM1.1 and PM2.0 of Shanghai, China, in spring, 2017. Environ. Sci. Pollut. Res. 2020, 27, 14690-14701. [CrossRef]

28. Ren, Y.; Zhou, B.; Tao, J.; Cao, J.; Zhang, Z.; Wu, C.; Wang, J.; Li, J.; Zhang, L.; Han, Y.; et al. Composition and size distribution of airborne particulate PAHs and oxygenated PAHs in two Chinese megacities. Atmos. Res. 2017, 183, 322-330. [CrossRef]

29. Nisbet, I.C.T.; LaGoy, P.K. Toxic equivalency factors (TEFs) for polycyclic aromatic hydrocarbons (PAHs). Regul. Toxicol. Pharmacol. 1992, 16, 290-300. [CrossRef]

30. US Environmental Protection Agency. Exposure Factors Handbook: 2011 Edition; EPA/600/R-09/052F; US Environmental Protection Agency: Washington, DC, USA, 2011; pp. 1-1466. 
31. Oswer U.S.E.P.A. Risk Assessment Guidance for Superfund Volume I: Human Health Evaluation Manual (Part F, Supplemental Guidance for Inhalation Risk Assessment); EPA: Washington, DC, USA, 2009; Volume I.

32. Del Rosario Sienra, M.; Rosazza, N.G.; Préndez, M. Polycyclic aromatic hydrocarbons and their molecular diagnostic ratios in urban atmospheric respirable particulate matter. Atmos. Res. 2005, 75, 267-281. [CrossRef]

33. Possanzini, M.; Di Palo, V.; Gigliucci, P.; Tomasi Scianò, M.C.; Cecinato, A. Determination of phase-distributed PAH in Rome ambient air by denuder/ GC-MS method. Atmos. Environ. 2004, 38, 1727-1734. [CrossRef]

34. Stockwell, W.R.; Kuhns, H.; Etyemezian, V.; Green, M.C.; Chow, J.C.; Watson, J.G. The Treasure Valley secondary aerosol study II: Modeling of the formation of inorganic secondary aerosols and precursors for southwestern Idaho. Atmos. Environ. 2003, 37, 525-534. [CrossRef]

35. Lelieveld, J.; Evans, J.S.; Fnais, M.; Giannadaki, D.; Pozzer, A. The contribution of outdoor air pollution sources to premature mortality on a global scale. Nature 2015, 525, 367-371. [CrossRef]

36. Agudelo-Castañeda, D.M.; Teixeira, E.C.; Schneider, I.L.; Rolim, S.B.A.; Balzaretti, N.; e Silva, G.S. Comparison of emissivity, transmittance, and reflectance infrared spectra of polycyclic aromatic hydrocarbons with those of atmospheric particulates (PM1). Aerosol Air Qual. Res. 2015, 15, 1627-1639. [CrossRef]

37. He, J.; Fan, S.; Meng, Q.; Sun, Y.; Zhang, J.; Zu, F. Polycyclic aromatic hydrocarbons (PAHs) associated with fine particulate matters in Nanjing, China: Distributions, sources and meteorological influences. Atmos. Environ. 2014, 89, 207-215. [CrossRef]

38. Tobiszewski, M.; Namieśnik, J. PAH diagnostic ratios for the identification of pollution emission sources. Environ. Pollut. 2012, 162, 110-119. [CrossRef] [PubMed]

39. Hwang, H.M.; Wade, T.L.; Sericano, J.L. Concentrations and source characterization of polycyclic aromatic hydrocarbons in pine needles from Korea, Mexico, and United States. Atmos. Environ. 2003, 37, 2259-2267. [CrossRef]

40. Kim, K.-H.; Kabir, E.; Kabir, S. A review on the human health impact of airborne particulate matter. Environ. Int. 2015, 74, 136-143. [CrossRef] [PubMed]

41. Hong, H.S.; Yin, H.L.; Wang, X.H.; Ye, C.X. Seasonal variation of PM10-bound PAHs in the atmosphere of Xiamen, China. Atmos. Res. 2007, 85, 429-441. [CrossRef]

42. Hamid, N.; Syed, J.H.; Junaid, M.; Mahmood, A.; Li, J.; Zhang, G.; Malik, R.N. Elucidating the urban levels, sources and health risks of polycyclic aromatic hydrocarbons (PAHs) in Pakistan: Implications for changing energy demand. Sci. Total Environ. 2018, 619-620, 165-175. [CrossRef]

43. Akyüz, M.; Çabuk, H. Gas-particle partitioning and seasonal variation of polycyclic aromatic hydrocarbons in the atmosphere of Zonguldak, Turkey. Sci. Total Environ. 2010, 408, 5550-5558. [CrossRef]

44. Chang, K.F.; Fang, G.C.; Chen, J.C.; Wu, Y.S. Atmospheric polycyclic aromatic hydrocarbons (PAHs) in Asia: A review from 1999 to 2004. Environ. Pollut. 2006, 142, 388-396. [CrossRef] [PubMed]

45. Li, H.; Wu, H.; Wang, Q.; Yang, M.; Li, F.; Sun, Y.; Qian, X.; Wang, J.; Wang, C.H. Chemical partitioning of fine particle-bound metals on haze-fog and non-haze-fog days in Nanjing, China and its contribution to human health risks. Atmos. Environ. 2017, 183, 142-150. [CrossRef]

46. Yunker, M.B.; Macdonald, R.W.; Vingarzan, R.; Mitchell, H.; Goyette, D.; Sylvestre, S. PAHs in the Fraser River basin: A critical appraisal of PAH ratios as indicators of PAH source and composition. Org. Geochem. 2002, 33, 489-515. [CrossRef]

47. Wu, Y.; Yang, L.; Zheng, X.; Zhang, S.; Song, S.; Li, J.; Hao, J. Characterization and source apportionment of particulate PAHs in the roadside environment in Beijing. Sci. Total Environ. 2014, 470-471, 76-83. [CrossRef]

48. Song, H.; Zhang, Y.; Luo, M.; Gu, J.; Wu, M.; Xu, D.; Xu, G.; Ma, L. Seasonal variation, sources and health risk assessment of polycyclic.pdf. Atmos. Pollut. Res. 2019, 10, 105-114. [CrossRef]

49. Dan, M.; Zhuang, G.; Li, X.; Tao, H.; Zhuang, Y. The characteristics of carbonaceous species and their sources in PM2.5 in Beijing. Atmos. Environ. 2004, 38, 3443-3452. [CrossRef]

50. De Kok, T.M.C.M.; Driece, H.A.L.; Hogervorst, J.G.F.; Briedé, J.J. Toxicological assessment of ambient and traffic-related particulate matter: A review of recent studies. Mutat. Res.-Rev. Mutat. Res. 2006, 613, 103-122. [CrossRef]

51. Traversi, D.; Festa, E.; Pignata, C.; Gilli, G. Aero-dispersed mutagenicity attributed to particulate and semi volatile phase in an urban environment. Chemosphere 2015, 124, 163-169. [CrossRef]

52. Akhbarizadeh, R.; Dobaradaran, S.; Amouei Torkmahalleh, M.; Saeedi, R.; Aibaghi, R.; Faraji Ghasemi, F. Suspended fine particulate matter (PM2.5), microplastics (MPs), and polycyclic aromatic hydrocarbons (PAHs) in air: Their possible relationships and health implications. Environ. Res. 2021, 192, 110339. [CrossRef] 